\title{
Floral expression and pollen germination ability in productive mountain papaya (Vasconcellea pubescens A.DC.) orchards
}

\author{
Marīa Angélica Salvatierra-González ${ }^{{ }^{*}}$, and Constanza Jana-Ayala ${ }^{1}$
}

\section{ABSTRACT}

Mountain papaya (Vasconcellea pubescens A.DC.) is described as trioecious in the centers of origin of Ecuador, Colombia, and Peru. However, under cultivation conditions in La Serena $\left(30^{\circ} \mathrm{S}, 70^{\circ} \mathrm{W}\right)$, Chile, it is found to be dioecious and monoecious. The objective was to learn about the variations in floral expression of mountain papaya. Flowers from monoecious and dioecious plants were therefore identified and quantified during two seasons. In vitro pollen germination ability was also evaluated based on the factors of site, season, and plant sex. Monoecious plant inflorescences are polygamous; female and male flowers are observed, as well as bisexual flowers that are usually deformed. This condition allows them to be classified as an ambisexual plant. The existence of flowers of different sexes appears to depend on the season; the female dioecious plant is maintained as such, independently of climatic conditions. Pollen from male flowers, from both ambisexual and male plants, germinates $75 \%$ in summer, while germination decreases to $56 \%$ in spring $(\mathrm{P} \leq 0.05)$. Flowering of female plants coincides with the permanent occurrence of male flowers in ambisexual plants, which ensures pollination without the need for male plants as pollinators in orchards. Based on this information, some management practices and possible lines of research about this species are proposed.

Key words: Ambisexual, dioecious, monoecious, pollen, Vasconcellea candamarcensis, Vasconcellea cundinamarcensis or Carica pubescens.
${ }^{1}$ Instituto de Investigaciones Agropecuarias, INIA Intihuasi, Colina San Joaquín S/N, La Serena, Chile.

"Corresponding author (asalvatierra@inia.cl).

Received: 3 July 2015

Accepted: 16 November 2015

doi:10.4067/S0718-58392016000200001

\section{INTRODUCTION}

The Caricaceae family consists of six genera, including Carica and Vasconcellea (Kyndt et al., 2005; Carvhalo and Rennes, 2012). Carica papaya L. is the only species of the genus Carica and the most studied. The genus Vasconcellea has 21 species, most of which are dioecious (19), but one species is monoecious ( $V$. monoica) and another is trioecious (V. pubescens A.DC.) just like $C$. papaya. The species cultivated in Chile, known as mountain papaya, is V.pubescens (Muñoz, 1988; Scheldeman et al., 2007).

The trioecious sexual type is considered rare, and it is suggested that it is derived from a dioecious ancestor (Aryal and Ming, 2013). Aguirre et al. (2009) defines V. pubescens as polygamous. Genetic studies of Vasconcellea have suggested the evolution of the chromosomes that determine sex (Wu et al., 2010); these would have been separated into different sequences for female and male plants based on unique sequences (Gschwend et al., 2013).

The centers with the greatest genetic diversity of Vasconcellea are Ecuador, Colombia, and Peru (Morales et al., 2004; Scheldeman et al., 2007). The biogeographic history of Caricaceae postulates that Carica moves away from Vasconcellea and its diversification is related to the origin of the Andes Mountains (Carvalho and Rennes, 2012). Carica papaya plants have sexual polymorphism in which different types of flowers are described (Storey, 1941; Ming et al., 2007). Horovitz and Jiménez (1972) indicate that $V$. pubescens consists of both female and ambisexual plants, inclusive term for plants with polygamous inflorescences. Meza et al. (2011) describe $V$. pubescens flowers from Colombia; they recovered female and male flowers from wild plants, but did not report any other type of flowers. Mountain papaya cultivated in Chile is assumed to be a trioecious plant (Carrasco et al., 2008), and is described as a dioecious (male and female plants) and monoecious plant with scarce bisexual flowers that produce deformed fruits (Muñoz, 1988). Other species of the Caricacea family, such as Jacaratia mexicana A.DC., exhibit sexual variations in hermaphroditic trees, which have female, male, and perfect flowers, they are defined as functional subdioecious plants (Aguirre et al., 2007; 2009).

Pistillate flowers of female and male trees also differ in size; this is attributed to the hypothesis of resource competition and because male flowers have a rudimentary pistil (Aguirre et al., 2009). These variations are not associated with external climatic factors. This is not the case for C. papaya, whose floral expression, just like other plants (Aryal and Ming, 2013), can be affected by climatic conditions such as temperature, relative humidity (Singh, 1990), and irrigation management (Terra de Almeida et al., 2003). 
Sexual polymorphism is gaining relevance because commercial orchard production is influenced by the number and quality of the fruits, which are variables determined by plant sex. Both ambisexual and female plants affect final production and female plants are preferred because of their higher quality fruit; this does not occur in C. papaya where hermaphroditic plants are preferred for fruit shape (Tamaki et al., 2011). To overcome this characteristic of mountain papaya, the nursery provides a unit consisting of three or four plants originating from seeds of unknown sex and the farmer thins outs the male plants 8-10 mo after planting in the orchard at the beginning of spring. However, because plants are not expressed simultaneously, this practice continues and affects management costs even more. Finally, the commercial orchard consists of an indefinite number of female and ambisexual plants, which affects productivity in mountain papaya orchards. For example, in La Serena, Chile, in two nearby orchards (Altovalsol and Algarrobito), the female: ambisexual ratio was $6: 1$ and $1: 1$, respectively. To date, there are no reports of floral expression in mountain papaya orchards in Chile during the seasons of the year, which leads to relying on types of sex associated with $C$. papaya or to the sexual type described in its centers of origin. This can generate erroneous agronomic practices if real floral expression of plant material cultivated in Chile is not considered.

Given that the objective was to learn about the floral expression of mountain papaya plants, defined as ambisexual and female, their sex and number was identified in each record; pollen germination ability was also evaluated in male flowers from both ambisexual and male plants. This knowledge will enable proposals of agronomic recommendations that are appropriate for the area under study.

\section{MATERIALS AND METHODS}

The study was conducted in two productive mountain papaya orchards located in areas typically associated with mountain papaya production, that is, Algarrobito (2956'34.8" S;

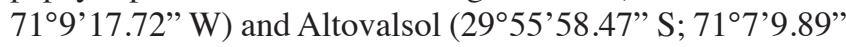
W), La Serena, Chile. Climatic conditions at both locations were similar with a mean temperature of $16.5{ }^{\circ} \mathrm{C}$ and mean relative humidity of $65 \%$ during the monitoring period. At these two locations, three plants with similar development were selected for each sex found in the orchards. Plants were identified at first flowering in August 2011 in order to start the evaluation the following year.

An inflorescence with closed flowers was selected in each of these plants under which a basket was installed to collect aborted flowers. The total number of developed flowers was counted three times per week and their sex was identified. Once flowering of the selected inflorescence finished, the basket was moved to a new upper axillary inflorescence. Monitoring occurred between January 2012 and June 2013.

A modification was made during the second season of evaluation to collect a greater number of flowers in each inflorescence. Collection of the developed axillary inflorescence was carried out weekly on the same plants that were tagged in the previous season. Subsequently, the different flowers were then counted according to their sex in the laboratory. Monitoring occurred between September 2013 and March 2014. Temperature and relative humidity data for the study period was provided by the nearest meteorological station of the Center for Advanced Studies in Arid Zones (CEAZA) network located in Gabriela Mistral (2958'33" S; 7108'33” W), Valle del Elqui.

\section{Pollen germination}

Pollen germination was monitored as a reliable test of viability in C. papaya (Parés-Martínez et al., 2004); the hypothesis was that the ability to germinate varies according to the period of flowering and the plant sex. Pollen was collected at both locations when flowers had slightly curved sepals. The procedure established by Parés-Martínez et al. (2006) was carried out; five male flowers were collected at each stage of ambisexual and male plants. Pollen was extracted with a test tube with $2 \mathrm{~mL}$ of $5 \%$ saccharose and incubated for $5 \mathrm{~h}$ in a growth chamber at $24{ }^{\circ} \mathrm{C}$ and 3000 lux. An aliquot was then extracted in which the number of grains of germinated (emission of pollen tube) and ungerminated pollen was counted in three fields of the microscope lens (40X). The percentage of in vitro germination was defined as grains of pollen with pollen tube/total grains $\times 100$ (Firmage and Dafni, 2001).

\section{Data processing and statistical analysis}

Inflorescence data in both the first and second seasons from each type of plant were averaged by recording date. Total counted inflorescences for plants of each sex were 72 . The number of new axillary inflorescences is reduced during winter; recordings were practically zero and data were therefore not considered. The information about female and ambisexual plants was processed independently for each of the study sites.

The analysis was a statistical description (mean \pm SD) for male, female, and bisexual flowers for each recording date and location. Pollen germination was analyzed by ANOVA for a completely randomized design. The interaction of the three factors Sex, Season, and Location was analyzed. Germination data were expressed as a percentage and transformed to $\sqrt{ }(\% / 100)$ before the statistical analysis (Bal and Abak, 2005). Duncan's test of multiple comparisons was applied to compare the means $(\mathrm{P} \leq 0.05)$ with the Statgraphics (Statpoint Technologies, Warrenton, Virginia, USA) statistical program.

\section{RESULTS AND DISCUSSION}

\section{Observed types of plants and flowers}

In accordance with Muñoz (1988), female plants with no alterations in flowering were observed in the orchards under study, and the sex of the flowers was maintained during the seasons of the year (Figures 1 and 2). However, the monoecious 
Figure 1. Seasonal variations in the sexual expression of female plant inflorescences in Altovalsol, Chile (means \pm SD).

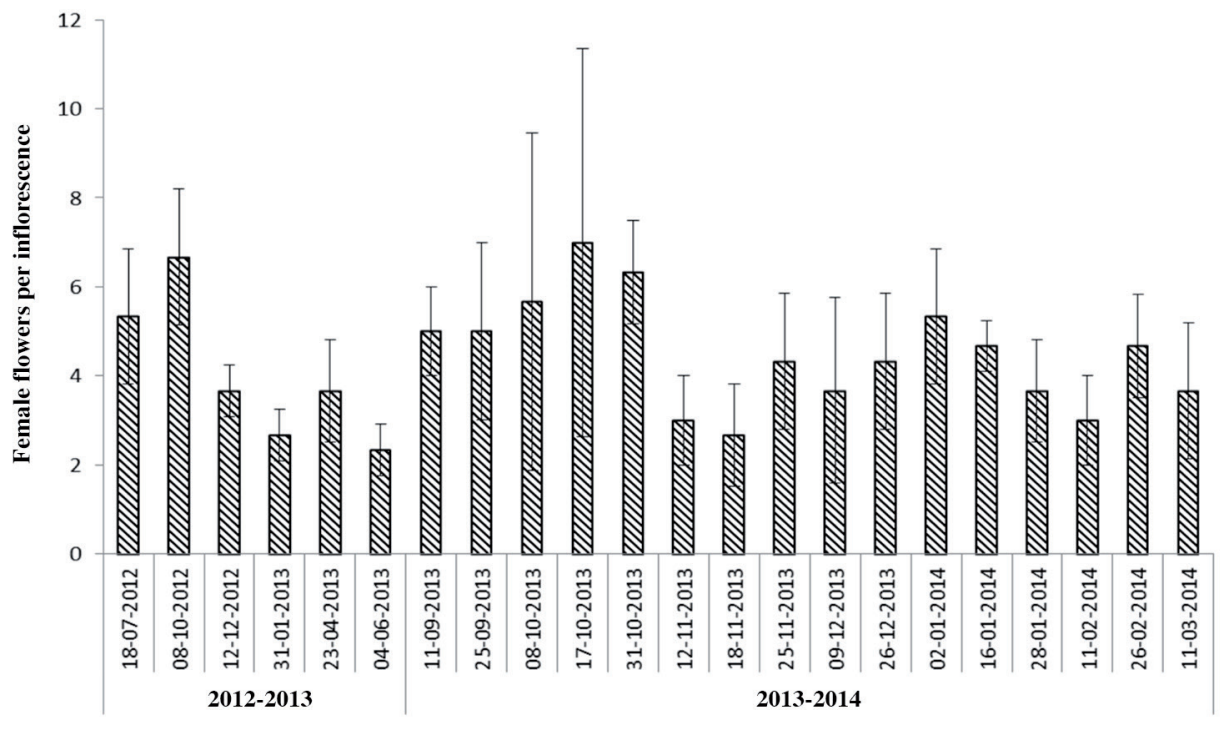

Figure 2. Seasonal variations in the sexual expression of female plant inflorescences in Algarrobito, Chile (means \pm SD).

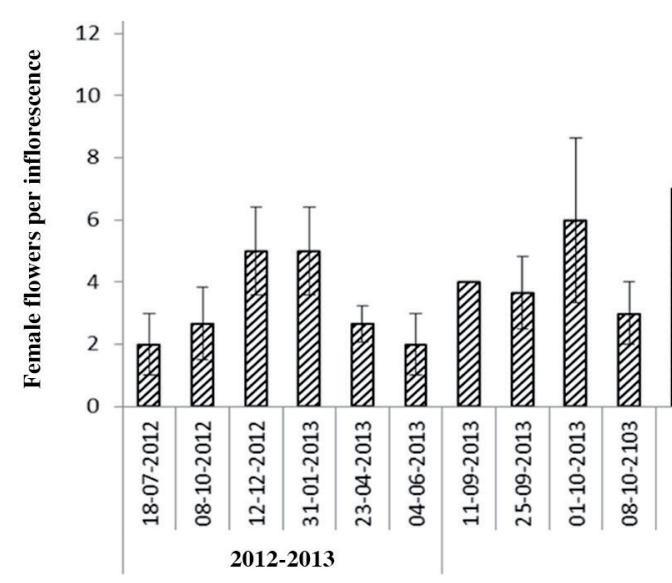

plant has inflorescences with both male and female flowers, and rarely with bisexual flowers. This partly agrees with the description by Muñoz (1988) (Figures 3 and 4), and totally agrees with the ambisexual plant definition (Horovitz and Jiménez, 1972) that implies polygamous inflorescences.

Figure 3. Polygamous inflorescence with three types of flowers.

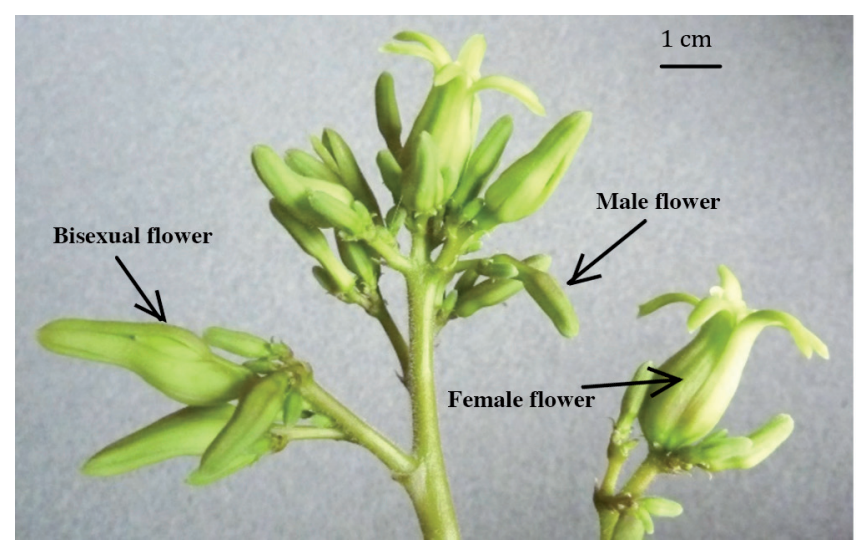

In the observed polygamous inflorescences, fruits are mostly from female flowers and bisexual flowers generally have a deformed carpel that gives it a curved shape (Muñoz, 1988). Male flowers always have a rudimentary pistil (Figure 4); this coincides with the description for C. papaya 'Maradol' (Gil and Miranda, 2005) and Jacaratia mexicana (Aguirre et al., 2009), and they amply surpass the number of female flowers found in the inflorescence. On the other hand, the female flowers differ in size and shape and are narrower in the ovary zone than the female flower of the female plant (Figure 5). This ultimately determines fruit shape.

\section{Floral evolution of ambisexual plants}

Plants exhibited changes in their sexual expression throughout the season at both study sites (Figures 6 and 7). Polygamous inflorescences are dominated by male flowers with a rudimentary pistil throughout the season, and female and bisexual flowers are mainly manifested during summer. It is only possible to observe male flowers in specific periods in spring (Figure 8). 
Figure 4. Types of common flowers in polygamous inflorescence found in orchards in La Serena.

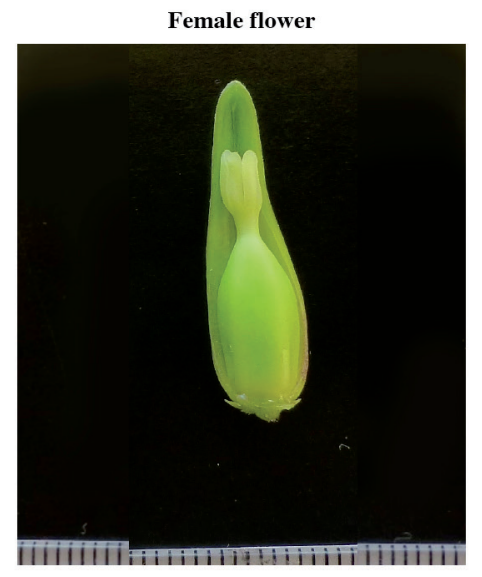

Corolla with free petals, well-developed pistil, short style, and stigma with five branches.

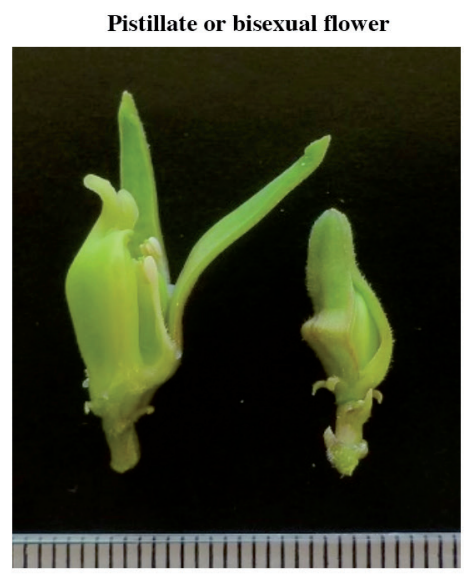

Short style, stigma with a variable number of branches, and deformed carpel. Exhibits stamens fused to the ovary walls. Produces deformed fruits.

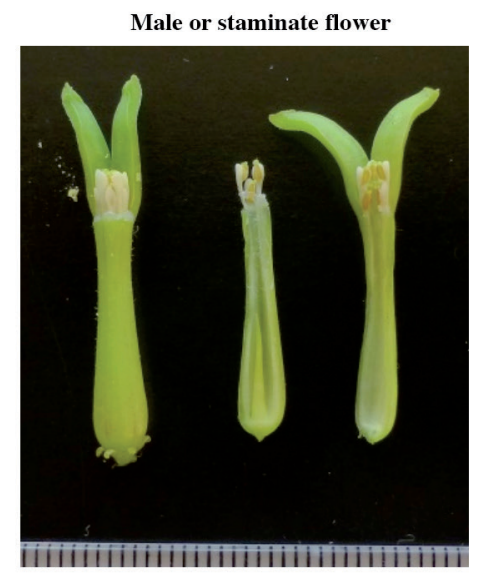

Free stamens exhibit a rudimentary pistil.
Figure 5. Female flowers of a female (left) and ambisexual (right) plant.

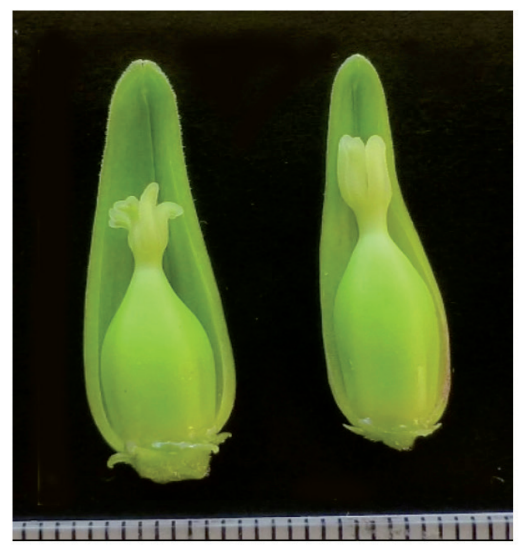

In the orchards under study, the genotype of the mountain papaya plants, originated from seeds, can explain the variations and number of flowers per inflorescence between plants. Floral expression in plants is influenced by various environmental factors (Singh, 1990; Wu et al., 2010; Aryal and Ming, 2013) and could explain the differences within the year, especially in spring when there is only an expression of male flowers. This may be linked with climatic factors, such as temperature and relative humidity, which modify the expression of Carica flowers (OECD, 2005); this cannot be detected in the present study. Floral expression can also be regulated by hormones (Wu et al., 2010).

Variations from polygamous inflorescences to only male flower inflorescences observed in ambisexual $V$. pubescens plants in the study area is similar to inflorescences observed in J. mexicana hermaphroditic plants, which, by producing

Figure 6. Seasonal variations in the sexual expression of ambisexual plant inflorescences in Altovalsol, Chile (means \pm SD).

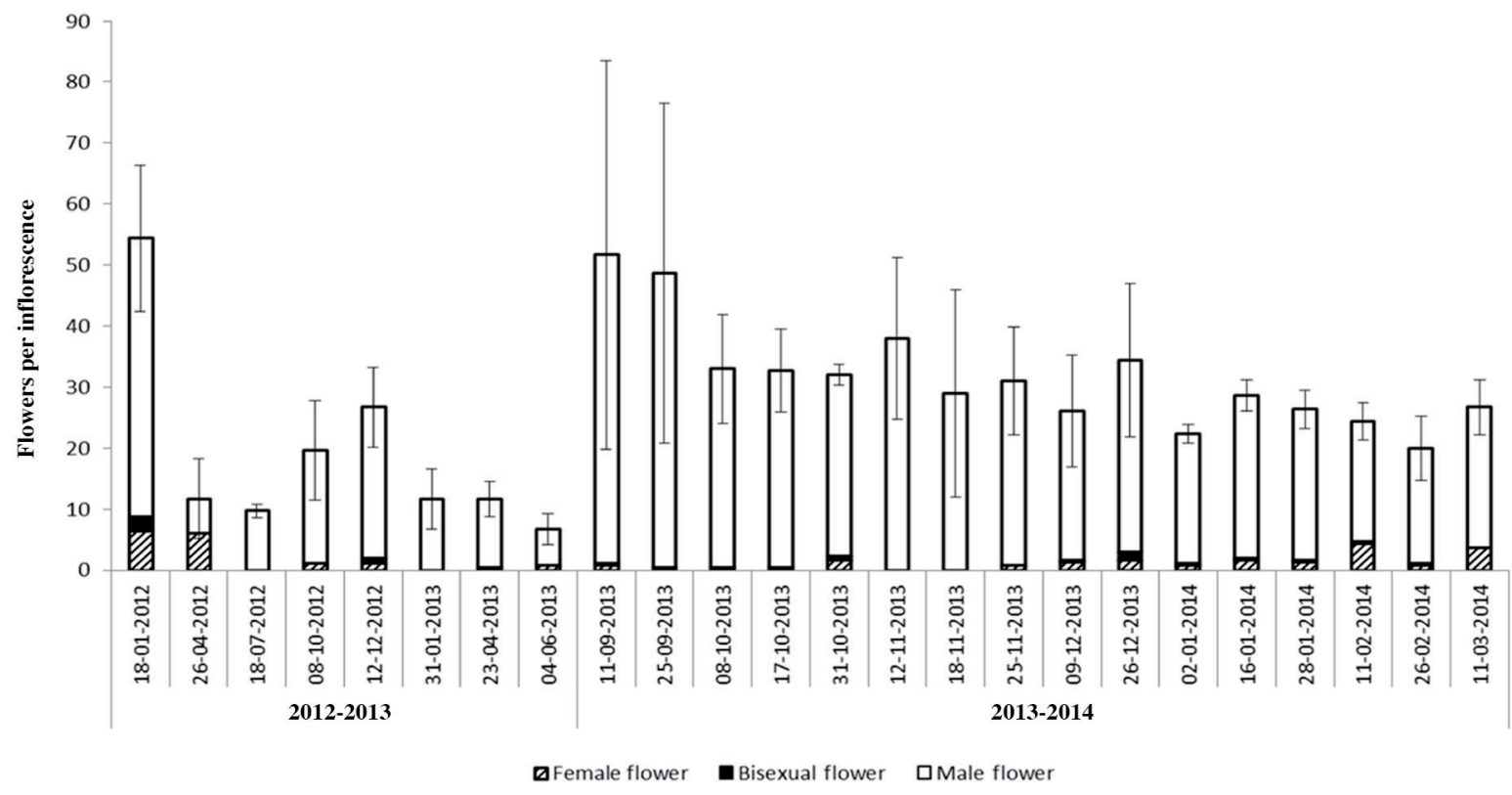


Figure 7. Seasonal variations in the sexual expression of ambisexual plant inflorescences in Algarrobito, Chile (means \pm SD).

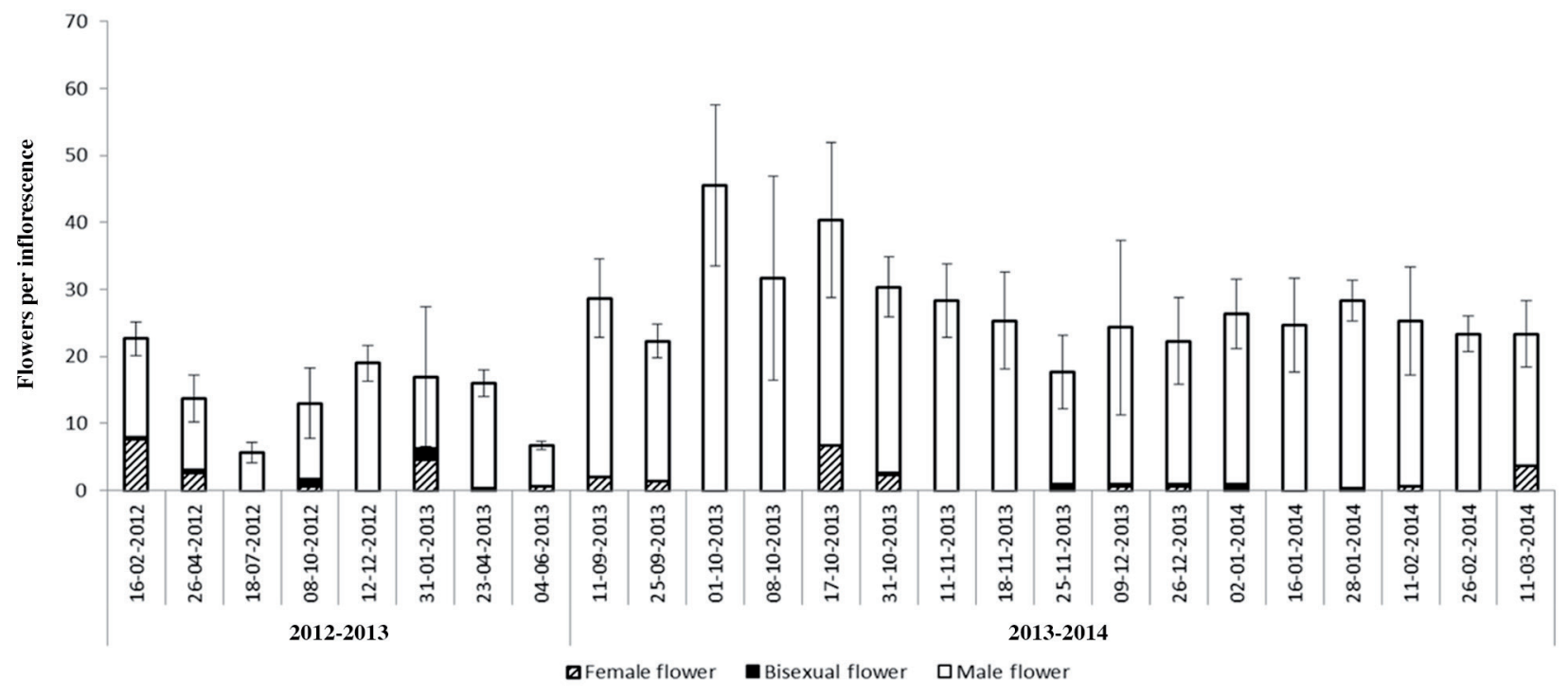

Figure 8. Seasonal variations in the sexual expression of inflorescences observed at both locations based on temperature and relative humidity $(\%)$.

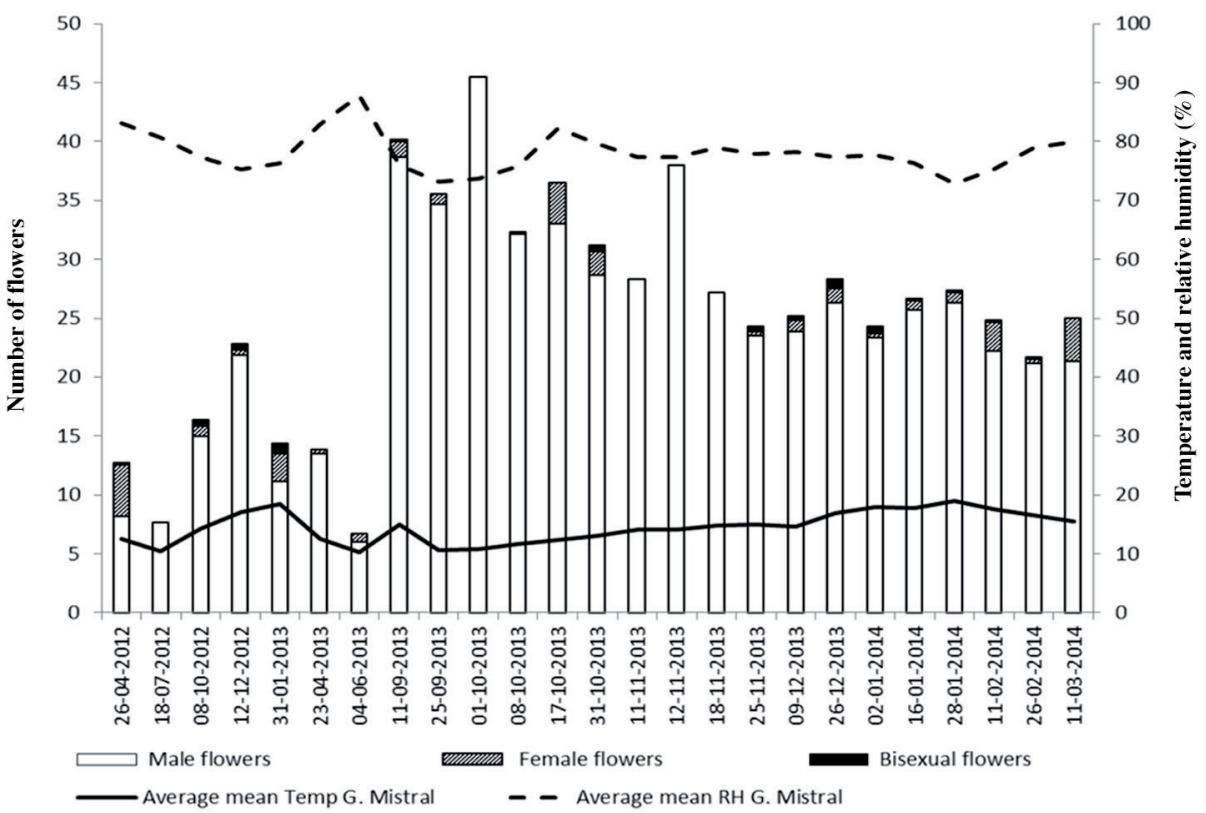

RH: Relative humidity, Temp: temperature, G. Mistral: Gabriela Mistral.

only male flowers, develop the three types of flowers (Aguirre et al., 2009). Under the observed behavior of ambisexual plants, female flowers would have viable pollen availability because of the permanent existence of male flowers that promote adequate pollination.

\section{Pollen germination}

Pollen germination depended on seasonality and not on plant sex originating from the donor flower or the location (Tables 1 and 2). This can be attributed to the proximity of the sites and the similar climatic conditions. With regard to plant sex, male flowers have the same characteristics and produce pollen with the same germination capacity. In $C$. papaya 'Cartagena', pollen germination increases as flower type approaches perfect maleness (Parés-Martínez et al., 2006); no perfect male flowers were observed in the present study. The degree of germination during summer is similar to the hermaphroditic 'Sunrise Solo' according to Tamaki et al. (2011), who indicate that the season of the year is a factor that influences germination capacity and is mainly due to temperature. Caetano et al. (2008) found that V. pubescens has pollen viability between $47.9 \%$ to $98.8 \%$ dependent of geographic location.

Finally, the proportion of male flowers in the ambisexual plants would produce enough viable pollen, especially in 
Table 1. Percentage of pollen germination of male flowers from ambisexual and male plants collected during two seasons at two locations.

\begin{tabular}{llcc}
\hline \multirow{2}{*}{ Factor } & & Algarrobito & Altovalsol \\
\cline { 3 - 4 } Season & & \multicolumn{2}{c}{$\%$ Pollen germination } \\
& Spring & $56.08 \mathrm{~b}$ & $59.74 \mathrm{~b}$ \\
& Summer & $75.32 \mathrm{a}$ & $75.42 \mathrm{a}$ \\
Plant sex & P F & 0 & 0 \\
& Ambisexual & $66.11 \mathrm{a}$ & $66.89 \mathrm{a}$ \\
\multirow{2}{*}{ Season $\times$ Sex } & Male & $64.85 \mathrm{a}$ & $70.03 \mathrm{a}$ \\
& P $>$ F & 0.4845 & 0.1429 \\
& P F & 0.063 & 0.15 \\
& CV \% & $8.31 \%$ & $7.36 \%$ \\
\hline
\end{tabular}

Different letters in the columns are significantly different according to Duncan's test $(\mathrm{P} \leq 0.05)$

P: probability, F: F-statistic, CV: coefficient of variation.

Table 2. Percentage of pollen germination in male flowers collected in the spring and summer at two locations.

\begin{tabular}{llc}
\hline Factor & & \% Germination \\
\hline Season & Spring & $58.09 \mathrm{~b}$ \\
& Summer & $75.38 \mathrm{a}$ \\
Location & P > F & 0 \\
& Algarrobito & $64.85 \mathrm{a}$ \\
Season $\times$ Location & Altovalsol & $67.56 \mathrm{a}$ \\
& P > F & 0.3207 \\
& P F & 0.366 \\
\hline
\end{tabular}

Different letters in the columns are significantly different according to Duncan's test $(\mathrm{P} \leq 0.05)$.

P: probability, F: F-statistic, CV: coefficient of variation.

the period with higher temperature; this is when there is a greater number of female flowers that make the presence of male plants unnecessary for pollination of this species.

\section{CONCLUSIONS}

In the study area, Vasconcellea pubescens exhibited dioecious (females and males) and monoecious plants. The monoecious plant has a polygamous inflorescence, that is, female, male, and bisexual flowers. Floral expression varied depending on time of year, which could be influenced by some environmental variables. There is a low number of bisexual flowers that can be observed mainly in spring and summer when they are functional and give rise to deformed fruits. Ambisexual plants, especially at the beginning of spring, can only have male flowers, so that eliminating undesirable plants (males) at post-planting should be done at the beginning of summer when female flowers are first observed.

Pollen from the male flowers of ambisexual plants shows the same germination as those of male plants, and the percentage of pollen germination is higher in summer than spring. Both situations would imply that male plants can be excluded in the productive orchards in the study area.

In-depth research about this species is required. It would be important to study the genetic expression of ambisexual plants of the mountain papaya cultivated in Chile, as well as evaluate their possible epigenetic responses. Similarly, a comparative study between $V$. pubescens found in Chile and Vasconcellea in its center of origin could indicate if the naturalization of this species subjected to endogamy is the cause of floral differentiation reported in ambisexual plants.

\section{ACKNOWLEDGEMENTS}

The authors thank the Fundación Innovación Agraria (FIA) for financing this research study through the project FIA PYT-2011-0060; we also wish to thank Lucía Martínez G. for recording field data, Cornelio Contreras S. for contribution to statistical analysis, as well as Raúl Meneses R. and Clara Medina Cano for their contributions to the manuscript.

\section{REFERENCES}

Aguirre, A., M. Vallejo-Marín, E.M. Piedra-Malagón, R. CruzOrtega, and R. Dirzo. 2009. Morphological variation in the flowers of Jacaratia mexicana A. DC. (Caricaceae), a subdioecious tree. Plant Biology 11:417-424. http://dx.doi:10.1111/j.14388677.2008.00154.x.

Aguirre, A., M. Vallejo-Marín, L. Salazar-Goroztieta, D.M. Arias, and R. Dirzo. 2007. Variation in sexual expression in Jacaratia mexicana (Caricaceae) in Southern Mexico: Frequency and relative seed performance of fruit-producing males. Biotropica 39(1):79-86. http://dx.doi:10.1111/j.1744-7429.2006.00230.x.

Aryal, R., and R. Ming. 2013. Sex determination in flowering plants: Papaya as a model system. Plant Science 217-218:56-62. doi:10.1016/j.plantsci.2013.10.018.

Bal, U., and K. Abak. 2005. Effects of sucrose, maltose, $\mathrm{pH}$ and phloroglucinol on the germination of globe artichoke pollen in vitro. European Journal Horticultural Science 70(3):142-148.

Caetano, C.M., T. Lagos, C. Sandoval, C. Posada, y D. Caetano. 2008. Citogenética de especies en Vasconcellea (Caricaceae). Acta Agronómica (Palmira) 57(4):241-245.

Carrasco, B., P. Avila, J. Perez-Diaz, P. Muñoz, R. García, B. Lavandero, et al. 2008. Genetic structure of highland papayas (Vasconcellea pubescens (Lenné et C. Koch) Badillo) cultivated along a geographic gradient in Chile as revealed by Inter Simple Sequence Repeats (ISSR). Genetic Resources and Crop Evolution 56:331-337. doi:10.1007/s10722-008-9367-1.

Carvalho, F.A., and S. Rennes. 2012. A dated phylogeny of the papaya family (Caricaceae) reveals the crop's closest relatives and the family's biogeographic history. Molecular Phylogenetics and Evolution 65:46-53.

Firmage, D., and A. Dafni. 2001. Field tests for pollen viability; a comparative approach. p. 88-94. In Benedek, P., and K.W. Richards (eds.) Proceedings of the $8^{\text {th }}$ International Pollination Symposium, Mosonmagyaróvár, Hungary. International Society for Horticultural Sciences (ISHS), Leuven, Belgium.

Gil, A.I., y D. Miranda. 2005. Morfología de la flor y de la semilla de papaya (Carica papaya L.): variedad Maradol e híbrido Tainung-1. Agronomía Colombiana 23(2):217-222.

Gschwend, A.R., C.M. Wai, F. Zee, A.K. Arumuganathan, and R. Ming. 2013. Genome size variation among sex types in dioecious and trioecious Caricaceae species. Euphytica 189:461-469. doi:10.1007/s10681-012-0815-9.

Horovitz, S., and H. Jiménez. 1972. The ambisexual form of Carica pubescens Lenné at Koch analized in interspecific crosses. Agronomía Tropical 22(5):475-482. 
Kyndt, T., E. Romeijn-Peeters, B. Van Droogenbroeck, J.P. RomeroMotochi, G. Gheysen, and P. Goetghebeur. 2005. Species relationships in the genus Vasconcellea (Caricaceae) based on molecular and morphological evidence. American Journal of Botany 92(6):1033-1044.

Meza, S.D., K. Osorio, y T. Lagos. 2011. Evaluación de crecimiento, la morfología floral y el fruto de Chilacuán (Vasconcellea cundinamarcensis B.) Revista de Ciencias Agrícolas 28:9-23.

Ming, R., Q. Yu, and P.H. Moore. 2007. Review. Sex determination in papaya. Seminars in Cell \& Developmental Biology 18:401-408. doi:10.1016/j.semcdb.2006.11.013.

Morales, A.R., D.L. Medina, and B.D. Yaguache. 2004. Genetic diversity, phylogeny and geographic distribution of the genus Vasconcella in Southern Ecuador. Lyonia 7(2):15-27.

Muñoz, M. 1988. Nomenclatura del papayo cultivado en Chile. Agricultura Técnica 48:39-42.

OECD. 2005. Section V. Reproductive biology. p. 24-28. In Consensus document on the biology of papaya (Carica papaya). Series on Harmonisation of Regulatory Oversight in Biotechnology Nr 33. ENV/JM/MONO (2005)16. Organisation for Economic Co-operation and Development (OECD), Paris, France. Available at http://www.oecd.org/ehs/ (accessed 24 November 2010).

Parés-Martínez, J., C. Basso, D. Jáuregui, y L. Meléndez. 2006. Cantidad, viabilidad y germinabilidad de los granos de polen de Carica papaya L. Revista de la Facultad de Agronomía de La Universidad del Zulia 23(2):172-180.
Parés-Martínez, J., R. Linárez, M. Arizaleta, y L. Meléndez. 2004. Aspectos de la biología floral en lechosa (Carica papaya L.) cv. «Cartagena roja», en el estado Lara, Venezuela. Revista Facultad de Agronomía, Caracas 21(2):116-125.

Scheldeman, X., L. Willemen, G. Coppens d'Eeckenbrugge, E. Romeijn-Peeters, M.T. Restrepo, J. Romero Motoche, et al. 2007. Distribution, diversity and environmental adaptation of highland papayas (Vasconcellea spp.) in tropical and subtropical America. Biodiversity Conservation 16:1867-1884. doi:10.1007/ s10531-006-9086-x.

Singh, I.D. 1990. Papaya. 224 p. Oxford and IBH Publishing, New Delhi, India

Storey, W.B. 1941. The botany and sex relations of the papaya. Hawaii Agricultural Experiment Station Bulletin 87:5-22.

Tamaki, M., N. Urasaki, Y. Sunakawa, K. Motomura, and S. Adaniya. 2011. Seasonal variations in pollen germination ability, reproductive function of pistils, and seeds and fruit yield in papaya (Carica papaya L.) in Okinawa. Journal Japanese Society Horticultural Science 80(2):156-163. Available at www.jstage. jst.go.jp/browse/jjshs 1 (accessed 19 April 2011).

Terra de Almeida, F., C.S. Marinho, E. Fernandes de Sousa, e S. Grippa. 2003. Expressão sexual do mamoeiro sob diferentes lâminas de irrigação na região Norte Fluminense. Revista Brasileira de Fruticultura 25:383-385.

Wu, X., J. Wang, J. Na, Q. Yu, R.C. Moore, F. Zee, et al. 2010. The origin of the non-recombining region of sex chromosomes in Carica and Vasconcellea. The Plant Journal 63:801-810. doi:10.1111/j.1365-313X.2010.04284.x. 